\title{
Pattern and Process of Population Migration in Assam
}

\author{
Sibani Basumatari \\ (Research Scholar, Department of Geography, Gauhati University, India)
}

\begin{abstract}
Human migration is a process of permanent or semi permanent change in usual residence of an individual or a group of people from one geographical area to another. Assam, a land with fertile soil and rich natural resources, attracts a large volume of migrants from both within and outside the country throughout the ages. The process and volume of internal migration, interstate migration and immigration contribute significant change of demographic structure of the state. As per 2001 Census, the volumes of inter-state migration and immigration in the region had been 5,15,924 (1.93 per cent of the total population) and 1,89,964 (0.71 per cent of the total population) as compared to total internal migrants of 59,21,753 (22.21 per cent of the total population) in the state. The nature and dimensions of migration in the state, however, vary both spatially and temporally depending on the processes of development activities and reasons behind migration.

The study is primarily based on secondary data obtained from Census of India volumes for the year 1991 and 2001. The data so obtained have been analysed with meaningful statistical techniques and presented with suitable cartographic techniques.
\end{abstract}

Keywords: Demographic structure, Interstate migration, Immigration, Magnitude of migration

\section{Introduction}

Migration is a form of spatial mobility or change of usual residence of person from one well defined geopolitical area to another. Migration cannot be considered a mere shift of people from one place of residence to another, as it is most fundamental to the understanding of continuously changing space content and space relationship of an area (Gosal,1961). Population migration is a common phenomena throughout the world. As a matter of fact, it is an instrument of cultural diffusion and social integration resulting significant change of landuse pattern and demographic profile in the area of origin and destination. The process of migration is considered as a illuminating agent of population change by influencing the area of inmigration, area of outmigaration and within the migrants themselves.

Assam being the land of veritable cauldron shelters around 3 per cent of the country's population presents a somewhat complex demographic character including rapid population growth and highly diverse population composition in terms of ethnicity, religion and language. Besides natural growth, the process of migration also contributes significant increase of population growth in Assam resulting declining land-man ratio, high unemployment and underemployment pressure in the labour market etc. Along with the various economic, demographic, social, political aspects, the fertile land, rich natural resource and ample scope of development in Assam always attracts the people from outside. The land of Assam experienced four phages of population immigration. The shortage of labour in the emerging tea industry of Assam bring large volume of tea labourer from the districts like Bihar, Uttar pradesh etc. as the first flow of migrants in the region followed by farm labourer from East Bengal (now Bangladesh) and third from Nepal. The fourth phage of migration inflow was the traders from the other states of India due to emerging scope of trade and commerce in the region (Devi, M. 2007).

The large volume of influx of migrants have modified the population structure of Assam in respect of ethno-religious composition, literacy and education pattern, occupational structure, age-sex composition, economy, work force etc. and host of associated population problems in changing socio-political disturbances like ethnic clash etc. People, who are unable to fulfill their needs within their geographical milieu and find it rather convenient to emigrate than to fight for a change, basically go for migration.

It may be mentioned here that, compare to the volume of immigration and inmigration into Assam, the volume of emigration from Assam to other part of the country and outside has still remained quite insignificant. Moreover, the population of migrants, both internal and external, is found to vary spatially across in state of Assam depending on availability of land and economic opportunities. Based on the above background, an attempt is made in this paper to understand the nature and dimensions of migration in Assam with respect to magnitude of migration, spatial distribution of migrants and causes behind migration in the state. 


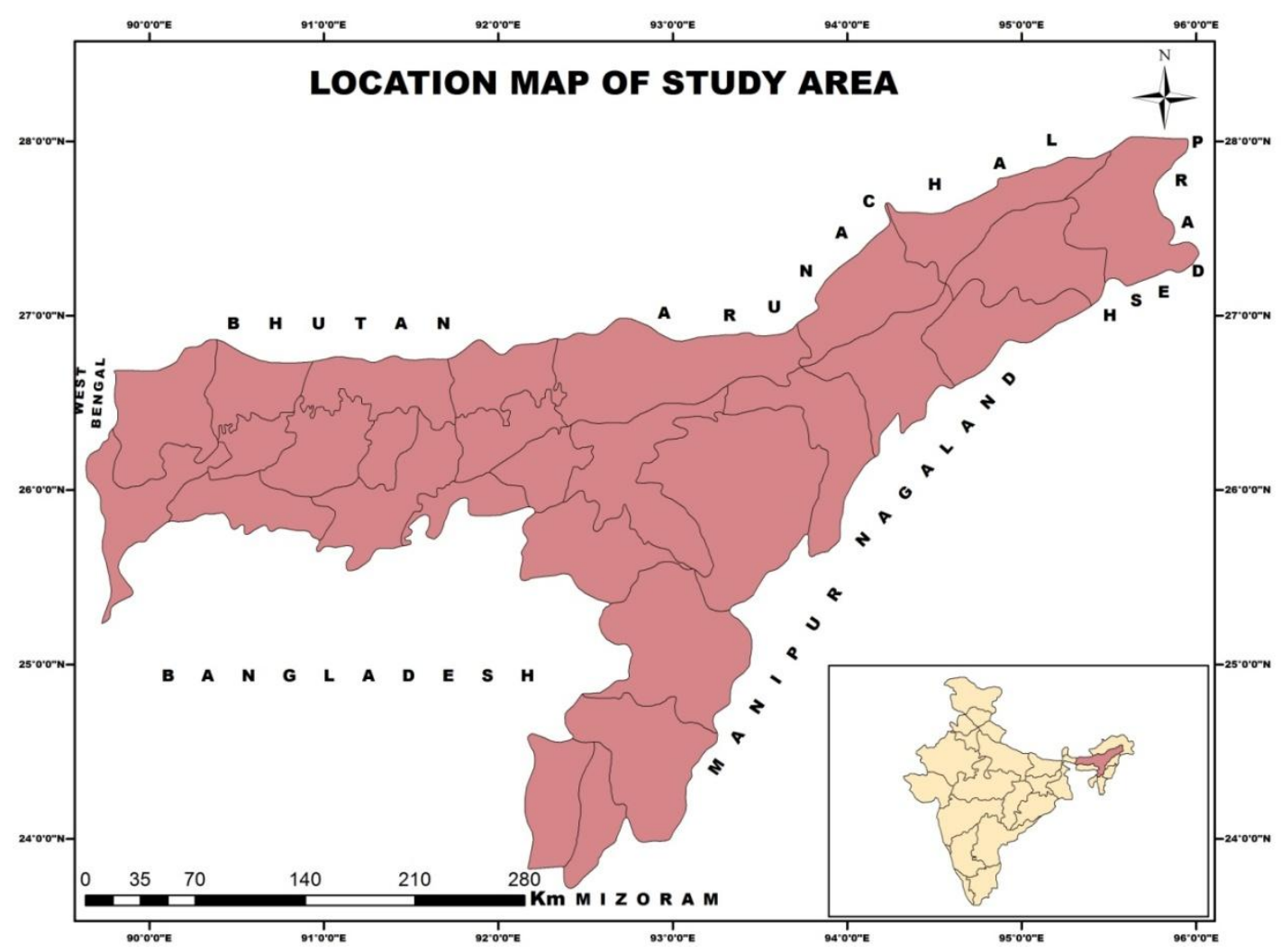

II. Database and Methodology

The study is primarily based on secondary data collected from Census of India and other government publications, covering the period 1991-2001, including some relevant books, journals, reports, periodicals, newspaper etc. have been consulted. The data so collected have been processed and analyzed with the help of meaningful statistical techniques like simple ratios and percentages. The summarized data have been skillfully presented through suitable maps and diagrams for clear exposition of the problem.

\section{Analysis and Discussion}

\subsection{Volume of migration into Assam from outside India}

Migration into Assam is not a recent phenomenon; it is an age old process since the British colonial period. However, it has occurred on a relatively larger scale in more recent decades particularly after 1971. Although migrants coming to Assam include people from the rest of India as well as from the neighboring countries of Bangladesh, Nepal and Pakistan, it is the second group which has been a focus of attention during last several years. The high population pressure on land drive huge influx of farm labourer from Bangladesh to Assam. The economic potentiality of the region along with reluctant nature of indigenous people and absence of capital and entrepreneurship made such immigration a vital one.

Out of the total population in Assam about 3.91 percent and 2.65 percent are migrants during 1991 and 2001, of which about 1.51 per cent and 0.71 per cent constitute as the international migrants for the respective years particularly from the countries like Bangladesh, Nepal and Pakistan.

In terms of the International migration, Bangladesh contributes the majority of the migrants $(84.85 \%$ and $86.14 \%)$ followed by Nepal (6.61\% and 9.39\%) and Pakistan (4.45\% and 3.72\%) respectively during 1991 and 2001 (Table 1 and fig 1).

TABLE 1: Volume of Migration (International) in Assam, 1991-2001

\begin{tabular}{|l|l|l|l|l|}
\hline \multirow{2}{*}{ Countries } & 1991 & 2001 & Percentage of total migrants \\
\cline { 2 - 5 } & No. of Migrants & Percentage of total migrants & No. of Migrants & 86.14 \\
\hline Bangladesh & $2,88,109$ & 84.85 & 164,144 & 9.39 \\
\hline Nepal & 22,433 & 6.61 & 17,896 & 3.72 \\
\hline Pakistan & 15,110 & 4.45 & 7,097 & 0.75 \\
\hline Others & 13,903 & 4.09 & 1,421 & 100 \\
\hline Assam & $3,39,555$ & 100 & 190,558 & 100 \\
\hline
\end{tabular}



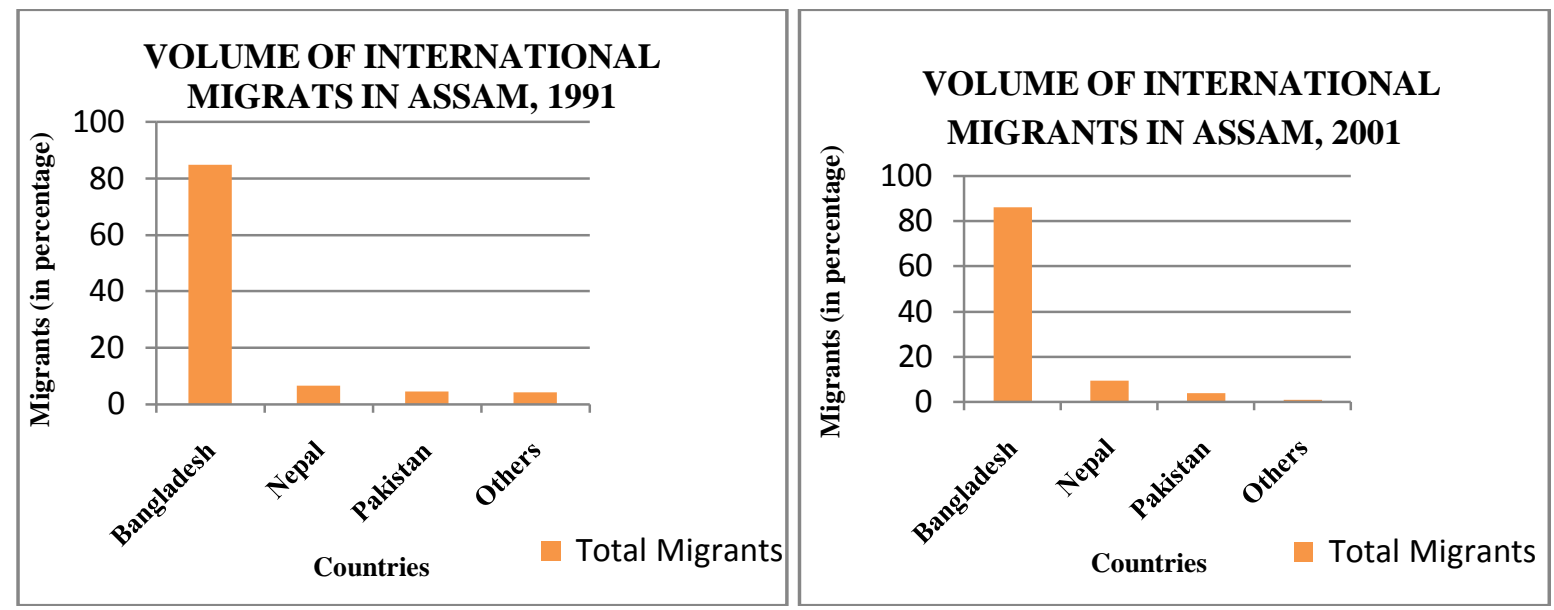

Fig. 1

\subsection{Volume of migration into Assam from other states of India}

Along with the international migration the migrants from the other states of India also contributes significant volume of population growth in Assam. Out of the total migrants, the interstate migrant into Assam contributes about 2.39 per cent and 1.93 per cent during 1991 and 2001.In both the consecutive year migrants from Bihar contributes highest volume of interstate migrants as about 36.31 per cent and 33.50 per cent respectively followed by West Bengal (17.62 per cent and 19.19 per cent) and Uttar Pradesh (10.17 per cent and 9.72 per cent) (Table 2). The bulk of another significant interstate migration is from the other states (17.55 per cent and 19.74 per cent) of the country mainly intensified by scope of trade and commerce. Apart from this the migrants from Tripura (6.91 per cent), Meghalaya (5.92 per cent) and Rajasthan (5.52 per cent) also contributes large volume of migrants to the region.

The existence of labour market, employment prospects in the destination area attracts the huge influx of migrants from the different districts of India, leading to structural disequilibrium and cultural mess-up in the region. The differential natures of migrant population from the different parts of the country along with the international migrants lead to the modification of the original population structure of the state of Assam. It also leads to the population redistribution among the states of the country, creating tension or pressure on the land of Assam and its indigenous population.

TABLE 2: Volume of Migration (other states of India) in Assam, 1991-2001

\begin{tabular}{|l|l|l|l|l|}
\hline \multirow{2}{*}{ States } & 1991 & 2001 & Percentage of total migrants \\
\cline { 2 - 5 } & No. of Migrants & Percentage of total migrants & No. of Migrants & 33.50 \\
\hline Bihar & $1,94,864$ & 36.31 & $1,72,825$ & 19.19 \\
\hline West Bengal & 94,548 & 17.62 & 99,034 & 9.72 \\
\hline Uttar Pradesh & 54,557 & 10.17 & 50,142 & 6.49 \\
\hline Tripura & 37,101 & 6.91 & 33,504 & 5.91 \\
\hline Meghalaya & 31,749 & 5.92 & 30,478 & 5.45 \\
\hline Rajasthan & 29,599 & 5.52 & 28,118 & 19.74 \\
\hline others & 94,161 & 17.55 & $1,01,823$ & 100 \\
\hline Assam & $5,36,579$ & 100 & $5,15,924$ & \\
\hline
\end{tabular}

Source: Calculated from Census of India, Migration tables by place of birth 1991, 2001

\subsection{Spatial variation of migrants from abroad and other states of India}

The volumes of migrants are unevenly distributed in different parts of Assam as per the prevailing factor of migration. The distribution of migrants are not homogenous throughout the state rather it is mainly concentrated in the plain regions than in the hilly regions. As per the 1991 data, the international migrant are found to be highest in Karimganj (3.56 per cent) district of Assam followed by Cachar (2.98 per cent), Bongaigaon (2.82 per cent) and Nagaon (2.56 per cent), while it is found to be highest in Cachar (1.63 per cent) followed by Karimganj (1.61 per cent), Bongaigaon (1.40 per cent) and Nagaon (1.13 per cent) during 2001 census (Table 3). The composition of highest concentration of migrant in the districts of Karimganj and Cachar is due to mainly political cause of the presence of International border with Bangladesh. 
Pattern and Process of Population Migration in Assam

TABLE 3: Spatial distribution of migrants from outside India, 1991-2001

\begin{tabular}{|c|c|c|c|c|c|c|c|c|c|}
\hline \multirow{2}{*}{$\begin{array}{l}\text { Sl. } \\
\text { No }\end{array}$} & \multirow[t]{2}{*}{ Districts } & \multicolumn{4}{|l|}{1991} & \multicolumn{4}{|l|}{2001} \\
\hline & & $\begin{array}{l}\text { Total } \\
\text { migrants }\end{array}$ & $\begin{array}{l}\% \text { of total } \\
\text { migrants }\end{array}$ & $\begin{array}{l}\% \text { of male } \\
\text { migrants }\end{array}$ & $\begin{array}{l}\% \text { of } \\
\text { female } \\
\text { migrants }\end{array}$ & $\begin{array}{l}\text { Total } \\
\text { migrants }\end{array}$ & $\begin{array}{l}\% \text { of total } \\
\text { migrants }\end{array}$ & $\begin{array}{l}\% \text { of male } \\
\text { migrants }\end{array}$ & $\begin{array}{l}\% \text { female } \\
\text { migrants }\end{array}$ \\
\hline 1 & Dhubri & 14,292 & 1.07 & 1.08 & 1.06 & 7,687 & 0.47 & 0.47 & 0.47 \\
\hline 2 & Kokrajhar & 13,314 & 1.66 & 1.80 & 1.51 & 8,666 & 0.93 & 0.97 & 0.89 \\
\hline 3 & Bongaigaon & 22,765 & 2.82 & 3.01 & 2.61 & 12,653 & 1.40 & 1.46 & 1.32 \\
\hline 4 & Goalpara & 12,311 & 1.84 & 1.96 & 1.72 & 7,860 & 0.95 & 0.95 & 0.96 \\
\hline 5 & Barpeta & 21,450 & 1.55 & 1.55 & 1.54 & 8,991 & 0.55 & 0.55 & 0.54 \\
\hline 6 & Nalbari & 9,860 & 0.97 & 1.02 & 0.91 & 5,577 & 0.49 & 0.51 & 0.46 \\
\hline 7 & Kamrup & 27,852 & 1.39 & 1.45 & 1.33 & 16,169 & 0.64 & 0.68 & 0.60 \\
\hline 8 & Darrang & 19,927 & 1.53 & 1.65 & 1.40 & 9,766 & 0.65 & 0.67 & 0.62 \\
\hline 9 & Sonitpur & 18,120 & 1.27 & 1.35 & 1.19 & 10,628 & 0.63 & 0.66 & 0.60 \\
\hline 10 & Lakhimpur & 6,070 & 0.81 & 0.88 & 0.73 & 2,968 & 0.33 & 0.36 & 0.30 \\
\hline 11 & Dhemaji & 7,133 & 1.49 & 1.66 & 1.30 & 3,044 & 0.53 & 0.58 & 0.48 \\
\hline 12 & Morigaon & 7,780 & 1.22 & 1.31 & 1.11 & 4,009 & 0.52 & 0.55 & 0.48 \\
\hline 13 & Nagaon & 48,481 & 2.56 & 2.72 & 2.39 & 26,131 & 1.13 & 1.17 & 1.09 \\
\hline 14 & Golaghat & 2,803 & 0.34 & 0.37 & 0.31 & 1,726 & 0.18 & 0.19 & 0.17 \\
\hline 15 & Jorhat & 2,392 & 0.27 & 0.32 & 0.23 & 1,414 & 0.14 & 0.16 & 0.12 \\
\hline 16 & Sibsagar & 1,960 & 0.21 & 0.25 & 0.18 & 1,171 & 0.11 & 0.12 & 0.10 \\
\hline 17 & Dibrugarh & 6,790 & 0.65 & 0.71 & 0.58 & 3,522 & 0.30 & 0.33 & 0.26 \\
\hline 18 & Tinsukia & 11,880 & 1.23 & 1.34 & 1.11 & 7,934 & 0.69 & 0.73 & 0.64 \\
\hline 19 & Karbi Anglong & 10,400 & 1.57 & 1.73 & 1.39 & 6,629 & 0.82 & 0.92 & 0.70 \\
\hline 20 & N.C.Hills & 2,010 & 1.33 & 1.70 & 0.90 & 1,198 & 0.64 & 0.78 & 0.49 \\
\hline 21 & Karimganj & 29,428 & 3.56 & 3.59 & 3.53 & 16,154 & 1.61 & 1.64 & 1.58 \\
\hline 22 & Hailakandi & 6,326 & 1.41 & 1.40 & 1.41 & 3,187 & 0.59 & 0.56 & 0.61 \\
\hline 23 & Cachar & 36,211 & 2.98 & 2.95 & 3.01 & 23,474 & 1.63 & 1.68 & 1.57 \\
\hline & Assam & $3,39,555$ & 1.51 & 1.59 & 1.43 & 190,558 & 0.71 & 0.74 & 0.68 \\
\hline
\end{tabular}

Source: Calculated from Census of India, Migration tables by place of birth 1991-2001

In respect of inmigrantion from other states of India is found to be highest in the district of Tinsukia ( 5.45 per cent and 4.43 per cent) for both the considered year while it is followed by the districts like Karbi Anglong (4.74 per cent and 3.53 per cent), Kamrup (4.68 per cent and 4.30 per cent), N.C.Hills (4.04 per cent and 2.92 per cent) and Dibrugarh (3.93 per cent and 2.92 per cent) etc. (Table 4). The opportunity of trade and commerce along with the requirement of cheap labour force in the districts of Assam attracted the interstate migrants to the region.

TABLE 4: Spatial distribution of migrants from other states of India, 1991- 2001

\begin{tabular}{|c|c|c|c|c|c|c|c|c|c|}
\hline \multirow{2}{*}{$\begin{array}{l}\text { Sl. } \\
\text { No. }\end{array}$} & \multirow[t]{2}{*}{ Districts } & \multicolumn{4}{|l|}{1991} & \multicolumn{4}{|l|}{2001} \\
\hline & & Total migrants & $\begin{array}{l}\% \text { of total } \\
\text { migrants }\end{array}$ & $\begin{array}{l}\% \text { of male } \\
\text { migrants }\end{array}$ & $\begin{array}{l}\% \text { of } \\
\text { female } \\
\text { migrants }\end{array}$ & $\begin{array}{l}\text { Total } \\
\text { migrants }\end{array}$ & $\begin{array}{l}\% \text { of total } \\
\text { migrants }\end{array}$ & $\begin{array}{l}\% \text { of male } \\
\text { migrants }\end{array}$ & $\begin{array}{l}\% \text { of } \\
\text { female } \\
\text { migrants }\end{array}$ \\
\hline 1 & Dhubri & $1,634,589$ & 1.83 & 0.68 & 2.04 & 21,993 & 1.34 & 0.68 & 2.04 \\
\hline 2 & Kokrajhar & 930,404 & 2.44 & 1.49 & 2.40 & 17,971 & 1.93 & 1.49 & 2.40 \\
\hline 3 & Bongaigaon & 906,315 & 2.66 & 2.15 & 2.35 & 20,369 & 2.25 & 2.15 & 2.35 \\
\hline 4 & Goalpara & 822,306 & 1.26 & 1.12 & 1.03 & 8,811 & 1.07 & 1.11 & 1.03 \\
\hline 5 & Barpeta & $1,642,420$ & 0.63 & 0.39 & 0.40 & 6,512 & 0.40 & 0.39 & 0.40 \\
\hline 6 & Nalbari & $1,138,184$ & 1.01 & 0.62 & 0.50 & 6,425 & 0.56 & 0.62 & 0.50 \\
\hline 7 & Kamrup & $2,515,030$ & 4.68 & 4.90 & 3.64 & 108,217 & 4.30 & 4.90 & 3.64 \\
\hline 8 & Darrang & $1,503,943$ & 2.00 & 1.32 & 1.10 & 18,243 & 1.21 & 1.32 & 1.10 \\
\hline 9 & Sonitpur & $1,677,874$ & 2.87 & 2.23 & 1.92 & 34,877 & 2.08 & 2.23 & 1.92 \\
\hline 10 & Lakhimpur & 889,325 & 1.51 & 1.82 & 1.07 & 12,943 & 1.45 & 1.82 & 1.07 \\
\hline 11 & Dhemaji & 569,468 & 2.15 & 1.99 & 1.31 & 9,454 & 1.66 & 1.99 & 1.31 \\
\hline 12 & Morigaon & 775,874 & 0.93 & 0.63 & 0.48 & 4,350 & 0.56 & 0.63 & 0.48 \\
\hline 13 & Nagaon & $2,315,387$ & 1.60 & 1.22 & 1.00 & 25,791 & 1.11 & 1.22 & 1.00 \\
\hline 14 & Golaghat & 945,781 & 2.24 & 2.42 & 1.68 & 19,540 & 2.07 & 2.42 & 1.68 \\
\hline 15 & Jorhat & $1,009,197$ & 2.12 & 2.80 & 1.82 & 23,546 & 2.33 & 2.80 & 1.82 \\
\hline 16 & Sibsagar & $1,052,802$ & 1.88 & 2.54 & 1.35 & 20,737 & 1.97 & 2.54 & 1.35 \\
\hline 17 & Dibrugarh & $1,172,056$ & 3.93 & 3.30 & 2.51 & 34,225 & 2.92 & 3.30 & 2.51 \\
\hline 18 & Tinsukia & $1,150,146$ & 5.45 & 5.18 & 3.61 & 50,983 & 4.43 & 5.18 & 3.61 \\
\hline 19 & Karbi Anglong & 812,320 & 4.74 & 4.04 & 2.99 & 28,713 & 3.53 & 4.04 & 2.99 \\
\hline 20 & N.C.Hills & 186,189 & 4.04 & 3.53 & 2.22 & 5,434 & 2.92 & 3.53 & 2.22 \\
\hline 21 & Karimganj & $1,003,678$ & 1.77 & 0.89 & 1.61 & 12,462 & 1.24 & 0.89 & 1.61 \\
\hline 22 & Hailakandi & 542,978 & 1.37 & 0.92 & 0.99 & 5,186 & 0.95 & 0.92 & 0.99 \\
\hline 23 & Cachar & $1,442,141$ & 1.59 & 1.32 & 1.33 & 19,142 & 1.33 & 1.32 & 1.33 \\
\hline & Assam & $26,638,407$ & 2.39 & 2.10 & 1.76 & 515,924 & 1.94 & 2.10 & 1.76 \\
\hline
\end{tabular}

Source: Calculated from Census of India, Migration tables by place of birth 1991- 2001 


\subsection{Pattern of Internal (within the state) migration}

The pattern of population movement also takes place within the districts of the state due to differential nature of availability of factors associated to migration. The pull and push factor plays an important role in this regard. The districts with higher pull factors such as better economic opportunity, education system; health system etc. intensify the occurrence of internal migration process within the state. On the other hand, the districts lacking in this respect push or repels the people to migrate to other districts of the state. The volume of internal migration is also not uniform throughout the region, as all the districts are not equally developed in terms of the availability of the basic facilities. In this regard, Kamrup district rewards 209532 and 284460 volume of migrants during 1991 and 2001 sharing about 10.48 per cent and 11.31 per cent of the total internal migrants of the state due to growing process of urbanization and ample availability of the amenities (Table 5). The occurrence of internal migration is also comparatively higher among the districts like Bongaigaon (82691), Tinisukia (80795) and Nagaon (80744) (2001 census) due to the presence of topographic suitability of the districts along with the scope of primary economic activity.

TABLE 5: Volume of Internal migration in Assam, 1991-2001

\begin{tabular}{|c|c|c|c|c|c|}
\hline \multirow[t]{2}{*}{ S1. No. } & \multirow[t]{2}{*}{ Districts } & \multicolumn{2}{|l|}{1991} & \multicolumn{2}{|l|}{2001} \\
\hline & & Total internal migrants & $\begin{array}{l}\text { Percentage of Internal } \\
\text { migrants }\end{array}$ & $\begin{array}{l}\text { Total internal } \\
\text { migrants }\end{array}$ & $\begin{array}{ll}\text { Percentage } & \text { of } \\
\text { Internal migrants } & \end{array}$ \\
\hline 1 & Dhubri & 39428 & 2.96 & 39543 & 2.42 \\
\hline 3 & Bongaigaon & 87101 & 10.79 & 82691 & 9.12 \\
\hline 4 & Goalpara & 41455 & 6.20 & 49928 & 6.07 \\
\hline 7 & Kamrup & 209532 & 10.48 & 284460 & 11.31 \\
\hline 8 & Darrang & 75872 & 5.84 & 67326 & 4.48 \\
\hline 9 & Sonitpur & 102538 & 7.20 & 119601 & 7.13 \\
\hline 10 & Lakhimpur & 46242 & 6.15 & 51883 & 5.83 \\
\hline 11 & Dhemaji & 97579 & 20.38 & 77814 & 13.66 \\
\hline 12 & Morigaon & 38416 & 6.00 & 36884 & 4.75 \\
\hline 16 & Sibsagar & 41190 & 4.54 & 54141 & 5.14 \\
\hline 17 & Dibrugarh & 70880 & 6.80 & 72614 & 6.19 \\
\hline 18 & Tinsukia & 76143 & 7.91 & 80795 & 7.02 \\
\hline 19 & Karbi Anglong & 62998 & 9.50 & 60088 & 7.40 \\
\hline 20 & N.C.Hills & 22246 & 14.75 & 20154 & 10.82 \\
\hline 21 & Karimganj & 24123 & 2.92 & 22451 & 2.24 \\
\hline 22 & Hailakandi & 20345 & 4.53 & 21219 & 3.91 \\
\hline \multirow[t]{2}{*}{23} & Cachar & 40829 & 3.36 & 34242 & 2.37 \\
\hline & Assam & 1455743 & 6.49 & 1535561 & 5.76 \\
\hline
\end{tabular}

Source: Calculated from Census of India, Migration tables by place of birth 1991 and 2001

\subsection{Reasons of migration by place of last residence}

The processes of human movement are always associated with number of reasons including social, cultural, political reasons, employment, business, education, marriage, family movement, etc. People move from one area to another for fulfillment of required and better facilities of amenities. The areas appalling poverty, unemployment, low and uncertain wages, uneconomic land holdings, poor facilities for education, health, recreation etc. move forward the people to migrate to another place where batter facility prevails. Thus, it is the push and pull factor acts as ingredients of population migration. Among all the reasons of migration, marriage (36.48 per cent) is considered as the single largest reason for migration. This reason of migration is more pronounced among the females (58.79 per cent) than the male (1.59 per cent) counterparts as female are forced to migrate under the social custom of marriage system. While after marriage, family movement (15.08 per cent) is also another prominent reason for migration followed by employment, ( 5.55 per cent) trade and commerce ( 2.83 per cent), movement after birth ( 1.03 per cent) and education ( 0.69 per cent) (Table 5). Most of the family movement form of migration is governed by religious and political reasons of migration process. The shortage of labour force in the primary and secondary sector of economic activity generates the employment opportunity which attracts the large volume of migrants into Assam both in the form of interstate and international migrants. Similarly, the lack of skill of trade and commerce among the people of Assam attracts the large volume of traders to the region. 
TABLE 5: Volume of migration due to different Reasons in Assam, 2001

\begin{tabular}{|l|l|l|l|l|l|l|}
\hline Reasons & No. of migrants & $\begin{array}{l}\text { Percentage } \\
\text { of migrants }\end{array}$ & $\begin{array}{l}\text { No. of Male } \\
\text { migrants }\end{array}$ & $\begin{array}{l}\text { Percentage of } \\
\text { Male migrants }\end{array}$ & $\begin{array}{l}\text { No. of Female } \\
\text { migrants }\end{array}$ & $\begin{array}{l}\text { Percentage } \\
\text { Female migrants }\end{array}$ \\
\hline Employment & 377143 & 5.55 & 329601 & 12.44 & 47542 & 1.14 \\
\hline $\begin{array}{l}\text { Trade and } \\
\text { Commerce }\end{array}$ & 192255 & 2.83 & 179166 & 6.76 & 13059 & 0.31 \\
\hline Education & 47026 & 0.69 & 32481 & 1.22 & 14545 & 0.35 \\
\hline Marriage & 2478625 & 36.48 & 42241 & 1.59 & 2436384 & 58.79 \\
\hline $\begin{array}{l}\text { Family } \\
\text { movement }\end{array}$ & 1024785 & 15.08 & 519776 & 19.62 & 505009 & 12.18 \\
\hline $\begin{array}{l}\text { Movement after } \\
\text { birth }\end{array}$ & 70631 & 1.03 & 47218 & 1.78 & 23413 & 0.56 \\
\hline Other & 2602391 & 38.31 & 1498274 & 56.56 & 1104117 & 26.64 \\
\hline
\end{tabular}

Source: Calculated from Census of India, Migration tables by place of last residence, 2001

\subsection{Socio- Economic Characteristics of the Migrant}

The socio economic character of migrant is very difficult to conceptualize as it varies from migrants to migrants and from place to place. The migrants belonging from striking different socio economic background have a significant influence on the modification of existing culture of an area. The pattern of socio economic character of migrant population shows larger volume of concentration of dependent population. The dependency ratio among the migrant is 56.03 per cent (2001 census), while it is larger among the females (43.77 per cent) than the male (12.26 per cent) counterparts. The overall work participation rate among the migrants is about 43.97 per cent. In this case also the male migrants (68.56 per cent) occupy the higher rate of work participation than the females (28.25 per cent).

TABLE 6: Socio- Economic Characteristics of the Migrant, 2001

\begin{tabular}{|l|l|l|l|}
\hline Socio- Economic Characteristics & $\begin{array}{l}\text { Total } \\
\text { (in percentage) }\end{array}$ & $\begin{array}{l}\text { Male } \\
\text { (in percentage) }\end{array}$ & $\begin{array}{l}\text { Female } \\
\text { (in percentage) }\end{array}$ \\
\hline Dependency ratio & 56.03 & 12.26 & 43.77 \\
\hline Work participation rate & 43.97 & 68.56 & 28.25 \\
\hline
\end{tabular}

Source: Calculated from Census of India, Migration tables, 2001

In terms of age sex composition pattern, about 75.60 per cent migrant population belongs to the age group of 15- 59 age, which shows larger volume of working population than the dependent population, while, in this respect females (78.78 per cent) percentage is larger than the male (70.63 per cent)ones. Out of the total migrants about 13.86 per cent constitutes $0-14$ age group and about 10.41 per cent constitutes 60 and above age group of migrant population (Table 7).

TABLE 7: Age- Sex composition among migrants in Assam, 2001

\begin{tabular}{|l|l|l|l|l|l|l|}
\hline Age group & Persons & Male & Female & $\begin{array}{l}\text { Percentage of } \\
\text { persons }\end{array}$ & $\begin{array}{l}\text { Percentage of } \\
\text { Male }\end{array}$ & $\begin{array}{l}\text { Percentage } \\
\text { Female }\end{array}$ \\
\hline $0-14$ & 941994 & 485541 & 456453 & 13.86 & 18.33 & 11.01 \\
\hline $15-59$ & 5135849 & 1870935 & 3264914 & 75.60 & 70.63 & 78.78 \\
\hline $60 \&$ above & 707628 & 208141 & 419487 & 10.41 & 10.87 & 10.12 \\
\hline
\end{tabular}

Source: Calculated from Census of India, Migration tables, 2001

\section{Conclusion}

The foregoing discussion reveals the clear exposition of migration pattern in Assam, in terms of International, Interstate and internal migration throughout the state. The prevalence of international migration from neighbouring countries leads to the unusual population growth in the boarder districts of Assam, contributing share in total population growth of the region. Migrants coming from diverse socio-economic background not only influence the demographic composition of the existing mass of population but also results in emergence of new problems like decline of man-land ratio, shortage of food, settlement pattern, and ethnic clash etc. in the region. The process of migration also modified the religious, linguistic and cultural composition, creating imbalance in the historic scenario of Assam. This process of population movement is also associated with the appearance of ethnic identity crisis among the indigenous people of Assam. It is thus highly essential on the part of the authorities concerned to take up appropriate measures to stop the influx of huge infiltration in the region and to short out the boarder issue with the neighbouring countries. Concurrently, the emphasis should be given to overall socio economic development of the region. 


\section{References}

[1]. Gosal, G.S., International Migration in India- A Regional Analysis, Indian Geographical Journal, 36, $1961,106-121$.

[2]. Devi, M., Economic History of Nepali Migration and Settlement in Assam, Economic and Political Weekly, 42(29), (Jul. 21-27, 2007), 3005-3007.

[3]. Rele, J. R., Trends and Significance of Internal Migration in India, Sankhyā: The Indian Journal of Statistics, Series B (1960-2002), 31(3/4), 1969, 501-508.

[4]. Renshaw, E., Birth, Death and Migration Processes, Biometrika, 59, (1), (Apr., 1972), 49-60.

[5]. De Jong Gordon F., Chamratrithirong, A. and Tran, Quynh-Giang. For Better, for Worse: Life Satisfaction Consequences of Migration, International Migration Review, 36,(3) 2002, 838-863.

[6]. Dass, Susanta Krishna., Immigration and Demographic Transformation of Assam, Economic and Political Weekly, 15, (19), (May 10, 1980), 850-859.

[7]. Goswami, S., Ethnic Conflict in Assam, The Indian Journal of Political Science, 62,(1), 2001,123-137

[8]. Misra, U., Immigration and Identity Transformation in Assam, Economic and Political Weekly, 34(21) (May 22-28, 1999), 12641271 .

[9]. Chandna, R.C., Geography of Population(Kalyani Publishers, New Delhi, 2007).

[10]. Census of India, Migration Tables, Series-4 Assam, volume 1, 1991

[11]. Census of India, Migration Tables, Series-4 Assam, volume 1, 2001. 